Revista Iberoamericana, Vol. LXVIII, Núm. 201, Octubre-Diciembre 2002, 1129-1142

\title{
ALBERTO GIRRI EN EL PRESENTE POÉTICO
}

\author{
POR \\ Alberto Villanueva \\ University of Central Florida
}

Este trabajo reflexiona sobre la producción de Girri, que se inicia en la Argentina de los años cuarenta con solitario rigor y creciente impersonalidad, creciente tachadura del "yo" poético, al mismo tiempo que sitúa al poema en un campo ético. Se reconoce deudora de Borges y se inscribe en una escritura propia de la modernidad de un siglo xx visto en sus inicios, de manera muy esquemática, como la relación directa entre una aceleración del tiempo y una consecuente contracción y dispersión del espacio. Hay una cierta similitud con una de las laderas del Mallarmé de Un coup de dés, la que cifraba el poema al potenciar una lectura espacial y temporal simultánea, al mismo tiempo que lo alejaba de sus referentes exteriores. En lo superficial, esto coincidía con un tiempo real homogeneizado, mundial y público, acorde al World Standard Time, que generaba un inmenso presente simultáneo. En lo interior, iba acompañado de una cierta dirección, un movimiento hacia adentro del lenguaje, según George Steiner en After Babel, que ahondaba y —añado—al mismo tiempo seccionaba su realidad semántica, hasta bordear la afasia ya en tiempos de las vanguardias.

Laura Riding y Robert Graves habían anunciado, a mediados de los veinte, la necesidad del poema que viene a la página, que no significaba otra cosa que una existencia previa, que defendía la insistencia de E. E. Cummings en "la [de los poetas] obsesión de hacer”, donde la técnica era vista como irrelevante para la escritura del poema (A Survey of Modernist Poetry 134). O como dirá Girri, "la tesis de que todo lo dado existe, pero a la vez no existe sino a través del poema que lo va creando” (Obra poética VI 184). Y si la poesía de Girri exige una lectura atenta a los trabajos del pensamiento a partir de una variedad de medios expresivos, entonces en este ensayo será preciso ver a su lado algunos ejemplos de alta tensión de esos referentes. Simplemente pretendo dejar constancia "teórica” de algo que ya es un hecho literario, que la obra de Girri deviene lugar de citas natural después de la vanguardia, porque representa una inmersión ensimismada en la lengua y el espíritu trabajados como “territorios” muy propios, en respuesta (des)creída, ética, ante un estado actual fragmentario de lengua y mundo.

1.

No es necesario ser pesimista o apocalíptico, aunque es preciso admitir que en medio de la mayor indiferencia contemporánea, para volver a preguntar con Hölderlin, “...¿¿y para 
qué sirven los poetas en tiempos difíciles?”, pregunta que encabeza el homónimo ensayo de Heidegger, quien parcialmente responde: "Ser poeta en tiempos difíciles significa seguir cantando la huella de los dioses fugitivos. Así entonces el poeta, que en tiempos oscuros para el mundo clama por lo sagrado. En el lenguaje de Hölderlin la noche del mundo es la noche sagrada”(91 y 94). ${ }^{1}$ Para el filósofo se trata de una mediación, de una suerte de sacro propósito que debe cumplir el poeta, quien debe resistirse a dejar todo un mundo al cuidado del lenguaje instrumental. Wallace Stevens, cuyos poemas prefería Alberto Girri traductor, comentaba por otra parte:

Es fácil decir como en tiempos recientes que todo tiende a devenir real o, mejor, que todo va en la dirección misma de la realidad, que va en la dirección misma de los hechos. Partimos de los hechos y volvemos a ellos, y volvemos a lo que deseamos que ellos sean, no a lo que eran o a lo que más a menudo permanece de ellos. La poesía de una obra de la imaginación ilustra constantemente la fundamental e interminable pugna con los hechos. (The Palm 206)

El poema vuelve a la realidad con una carga que no está dada en esa realidad, esto es, fuera de la intervención (¿o de la mediación?) imaginativa del hacedor. En otro lugar, dice Wallace Stevens:

\begin{abstract}
Las cosas que tienen su origen en la imaginación o en las emociones (los poemas), por lo general tienen significados que difieren en naturaleza de los significados de aquellas que tienen su origen en la razón. Tienen significados imaginarios o emocionales, no racionales, que transmiten a personas susceptibles a esos significados. $Y$ estos pueden no significar nada para aquellos abiertos sólo a lo racional. En resumen, las cosas que tienen su origen en la imaginación o en las emociones toman a menudo una forma ambigua e incierta. No es posible atribuirles un único significado racional sin destruir lo que tienen propiamente de ambiguo e incierto. De ahí que a los poetas no les guste explicar. (82526, énfasis mío)
\end{abstract}

Dos posibles soluciones convergentes hacia la necesidad o el acto de ser y estar en el mundo, sea del poeta (Heidegger), o del poema (Stevens). Más humilde o más justa parece la elección de Wallace Stevens, en cuanto a su delimitar el ámbito y la esfera de influencia del poema. Aquí no hay una función, pudiérase decir, de algún modo exclusivamente central o salvadora para el ser en la sociedad, lo cual parece que es el caso de la asignación heideggeriana. Más bien, el poema ocupa un puesto al lado de tantos otros, en este caso se lo agrupa entre las entidades que están en el origen de la imaginación y de las emociones. ${ }^{2}$ Se lo excluye del listado de las significaciones racionales. Ahora bien, ¿es que el poema está realmente en el mundo? Emmanuel Lévinas no lo cree así (130-43). No al menos en el sentido de Heidegger: es para él una cosa (inerte) entre las cosas, o, más propiamente, una imagen del objeto, su representación. Su sombra. No participa de la esfera de lo racional porque sencillamente no es un concepto, no puede explicar, hacer

\footnotetext{
${ }^{1}$ Todas las versiones del inglés y del francés son mías.

2 “Imagen”, según Joan Corominas, como “'representación, retrato’ - de la misma familia que imitari, 'remedar”' (Breve diccionario etimológico 331).
} 
inteligible al objeto, función reservada para la crítica. Para Lévinas, "si el arte consiste en substituir el ente por su imagen, entonces el componente estético — como indica la etimología de esta palabra— es la sensación” (134, énfasis mío). Y para Deleuze-Guattari, "lo que se conserva, ya de la cosa, ya del objeto artístico, es un bloque de sensaciones, un compuesto de percepciones y afectos” (164). Sin embargo, el poema a su vez sí puede, como sombra que es, ser interpretado por el poeta en tanto éste asuma la función crítica: "La ambivalencia de la escritura es tal — dice Paul de Man—, que puede ser considerada a la vez como un acto y su proceso interpretativo subsiguiente, proceso que no tiende a coincidir con su objeto. De manera que la escritura alternativamente afirma y niega su propia naturaleza o especificidad" (Blindness and Insight 152). ${ }^{3}$ Porque el ser moderno no se limita a la página, es ahora un impulso radical, en palabras de Paul de Man en el mismo lugar, busca el acto, como insiste a continuación en esta traducción suya de Nietzsche: “Así, la persona para actuar debe hacerlo, según Goethe, sin consciencia y sin sabiduría. Debe olvidarlo todo para hacer algo, olvidar lo que ha sido, para conocer únicamente los derechos de lo que deviene como resultado de su propia acción”(147).

Para un deslinde propio a la naturaleza del poema en el mundo, es interesante recordar con de Man que "sería desafortunado, por ejemplo, confundir la materialidad del significante con la materialidad de lo que significa” (Resistance to Theory 11).Y vuelvo a Lévinas cuando considera que la crítica es el punto de encuentro o la instancia mediadora, vinculadora, entre la obra de arte literaria y el mundo real humano. Pero la obra es cerrada en su capacidad de producir eventos, es una irrealidad detenida, congelada y aparte (13043). Estamos de algún modo ante una entidad completa:

El artista se detiene porque la obra rechaza aceptar algo más, se le aparece como saturada. La obra está completa a pesar de las causas sociales y materiales que la interrumpen. No se entrega como al comienzo de un diálogo.

Esta plenitud no necesariamente justifica la estética académica del arte por el arte, fórmula falsa en tanto sitúa al arte por encima de la realidad y no reconoce magisterio alguno, e inmoral por cuanto libera al artista de sus deberes como ser humano y le asegura una pretenciosa y fácil aristocracia. Pero una obra no podría pertenecer al arte si no tuviese esa estructura formal plena, si por lo menos en esta dirección no hubiese quedado libre de responsabilidad. (131)

La obra muestra incapacidad para devenir, transformarse, una imposibilidad de salvación: algo que es básicamente inhumano; representa una inmovilidad del instante que no es solidaria con la realidad. En este sentido, piensa Lévinas:

Que los caracteres en un libro estén obligados a la infinita repetición de los mismos actos y pensamientos no se debe simplemente a los hechos contingentes de la narrativa, que es exterior a ellos mismos. Estos pueden ser narrados porque su ser (ahí) se parece a sí mismo, se duplica e inmoviliza. Tal fijeza es enteramente diferente de aquella otra de los conceptos, la cual da inicio a la vida, ofrece una realidad a nuestros poderes, a la verdad, abre una dialéctica. Por su reflexión en una narrativa, el ser de los caracteres conserva una

${ }^{3}$ Dejo de lado, deliberadamente, el énfasis “desconstruccionista” en la objetividad o impersonalidad de la escritura. Participo de una recuperación moderada de la subjetividad. 
fijeza no dialéctica, detiene el tiempo y la dialéctica. (139)

Paul Ricoeur, que ha meditado profusamente en torno a estas cuestiones, dice: “El evento más que la experiencia expresada y comunicada es la reciprocidad intersubjetiva misma, el acontecer del diálogo. La instancia del discurso es la instancia del diálogo” (Interpretation Theory 16, énfasis mío). Porque aquí el evento está situado en el corazón de la mediación, esto es, fuera de la obra, es el discurso mismo.Y es éste un desplazamiento que demuestra, consolida, la necesidad de la crítica, en cuanto lenguaje que está hablándole al otro, lenguaje que va de un lector-intérprete a otro, que recupera para sí una capacidad comunicadora que había quedado expectante, al borde del abismo. En este sentido, el prólogo, las notas, los comentarios del autor acerca de su propia obra se sitúan, a su vez, en esta otra dimensión, en este querer ir más allá, que sólo es viable por el diálogo. O, como en el caso de Girri, cuando el poema se torna reflexivo. Así en "Prosa textual”:

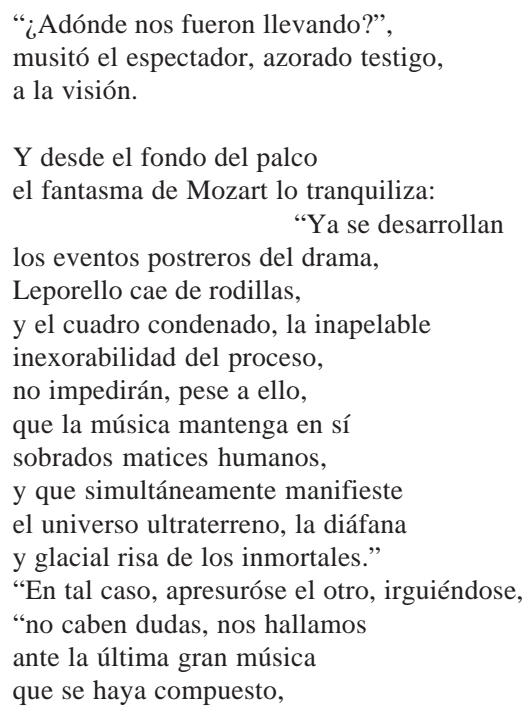

Y refiriéndose a estos tres últimos versos dice en sus anotaciones en Diario de un libro (1972), para el mes de mayo, y jueves 20: "El juicio del espectador sobre la música de Mozart parece puramente irracional, sólo catarsis, ninguna reflexión. ¿Como si fuera el 'ideal spectator' al que se dirige Mozart? ¿El imaginario y perfecto interlocutor de la obra, que cada artista persigue?” (Obra poética III 70). ${ }^{4}$ Y, también, entre otras:

\footnotetext{
${ }^{4}$ A propósito de esta idealización, dice Walter Benjamin: "En la valoración de una obra de arte o de una forma artística, tener en cuenta al receptor nunca ha sido fructífero. No sólo es errónea toda referencia a un cierto público o a sus representantes, sino que el mismo concepto de receptor 'ideal' va en detrimento de toda consideración teórica del arte, puesto que únicamente coloca la existencia y naturaleza humanas en cuanto tales. Si bien el arte también expone la existencia física y espiritual del ser humano, ninguno de sus trabajos busca una respuesta precisa. Ningún poema considera a sus
} 
Domingo 10

"Prosa textual". Fragmento de prosa, discurso corriente, transformado en poema. Con idénticas palabras, lograr una forma distinta de comunicar lo mismo. Lo que se pondría de relieve no es el significado de lo que se dice, sino una precisión diferente. (67)

Una precisión que es el devenir de la atención que se vuelca sobre la sintaxis, sobre el aire pasando entre las letras, también sobre lo que no está, una atención sin una narrativa que la distraiga. Para Ricoeur hay una dialéctica de evento y significado en el discurso así como una dialéctica entre el sentido y el referente en el significado mismo (23). Girri propone sustraer el evento de la prosa hacia el poema, y así dotarlo de una fuerza reflexiva idéntica. Entre prosa y poesía, en este punto, habría una atracción permanente, y, entonces, ciertos méritos de una pasarían a la otra, constantemente, en favor de una "precisión diferente”, un aumento de la atención. Quizás, esto favoreciera una depuración más natural del lenguaje, una necesaria oxigenación para las muy deterioradas palabras de la tribu, en Hispanoamérica. ${ }^{5}$ Natural, literalmente hablando, en el sentido que Deleuze-Guattari entienden el pasaje, el devenir-animal o planta, por ejemplo, de unos caracteres de novela, no visto como una transformación de uno en otro sino como algo pasando del uno al otro, y "este algo puede ser especificado sólo como sensación” (173).

En el mismo Diario, el martes 24 de agosto, Girri anota: "Poemas como aforismos. La prueba de su eficacia consistiría en que poemas así ocuparían más lugar en la memoria que en la página. Como ocurre en el estilo o en la imaginación aforística, el lector encontrará placer o disgusto renovados incesantemente, porque ese texto es parte de él" (110).

Y dice al respecto Sergio Cueto, en su excelente Seis estudios girrianos:

Al definir tautológicamente, el aforismo pronuncia, pues, una sola palabra: “Tal”, "Así”. Enseña el modo en que el poema es. Pero el poema enseña lo que ya sabía. Por eso la enseñanza del aforismo se limita a una seña, un gesto de reconocimiento: "Tal”, "Así". El aforismo reconoce al poema en su ser, lo reconoce antes de todo conocimiento, empieza por reconocerlo. Saber no es reconocer; reconocer es saber, porque saber es haber sabido. Saber es recordar, preservar en la memoria. El aforismo es el sabio recuerdo de lo que ya se sabía. Pero la memoria es la sabiduría misma, paciencia que todo lo acoge, soltura que lo acuerda todo, en la insignificancia del único llamado. ${ }^{6}$ (70-71)

lectores, ningún cuadro a quienes lo miran, ninguna sinfonía a sus oidores” (“The Task of the Translator” 69). Lo cual parece señalar el campo alusivo en la reflexión crítica de Girri respecto a su poema.

${ }^{5}$ Algo que se puede apreciar en la escasez de pensadores en Hispanoamérica, en relación con su inmensidad geográfica y su población. En el ámbito de la lengua, donde hay una evidente representación del pensamiento contemporáneo es en España.

6 "Aforismo significa, en sentido estricto, lo que separa del resto y determina: de-finitio, definición. El aforismo delimita, localiza el lugar vacío del poema diciendo: A es B, o mejor: A es A”, define Cueto (70). 
Poesía crítica comprende una línea de pensamiento en el poema. Pensar es reconocer, ejercitar la memoria, esto es, dejar entrar la historia. ${ }^{7} \mathrm{O}$ el ciclo, como dice Girri, quien afirma que el ejercicio de su poetizar es similar al acto de sembrar:

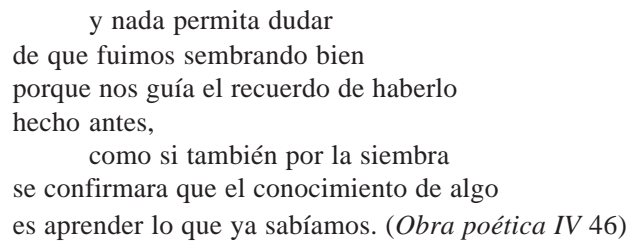

El poema de Mallarmé Un coup de dés señalaba un momento crítico del arte poética, un punto que no admite retorno para la actualidad. Porque era el hallazgo de una nueva "ley teórica”, se podría decir de modo análogo al de las leyes matemáticas. El poema se aleja de la realidad referencial, se trata de una realidad simbólica autosuficiente; ahora estamos ante un objeto simbólico predominantemente interior — “lírico”—intertextual y elusivo. Un mundo analógico, sí, pero con una considerable reducción del campo metafórico y un deslizamiento metonímico: Un coup de dés es un poema compuesto de una sola frase, con una "preponderancia de la categoría del sustantivo sobre la del verbo", ha señalado Julia Kristeva (274). Por eso resultan tan poco verdaderas todas esas experiencias de escritura que ignoran esta novedad, o que trabajan con ánimo de nostálgica restauración. Haroldo de Campos refiere el hallazgo de este modo, en "Superación de los lenguajes exclusivos":

Se trata de un poema que se cuestiona a sí mismo sobre la esencia del poetizar, en un sentido muy diferente, sin embargo, de las “artes poéticas” versificadas de la preceptiva tradicional: lo que está en proceso no es un recetario de cómo hacer poesía, sino una indagación más profunda de la peculiar verdad del poema, una experiencia de límites. Así el lenguaje del ensayo y de la especulación teórico-filosófica (langage de formulation, para usar un término de las “Tesis” del Círculo de Praga) pasa a integrarse al poema, que se hace metalenguaje de su propio lenguaje-objeto. (292)

Un pensar que es lo que Lévinas no da por sentado en tanto se es artista, de allí que sea erróneo considerar —inmediatamente—a las artes como uno de los más altos índices de civilización: "[l]a crítica trata al artista como persona en obra. Ya al inquirir en las influencias que éste sobrelleva, sitúa al orgulloso y libre individuo en la historia real”(142). Por otro lado, y de manera adicional, porque la crítica es central en su obra, Alberto Girri había querido “que las palabras no [fuesen] símbolos sino existencias”(Obra poética III 79). Éste es el solo modo de situar “[a] la poesía entendida como una manera de organizar la realidad, no de representarla”:

\footnotetext{
7 "El poeta no piensa antes del poema, sino despuús del poema”, dice Wallace Stevens mediante Enrique Pezzoni en diálogo con Girri (Obra poética IV 149).
} 


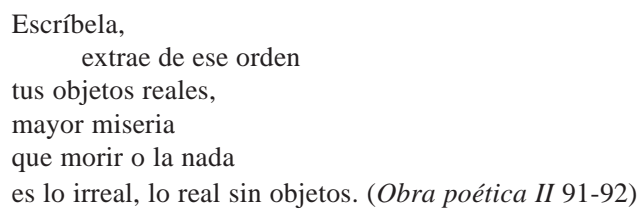

2.

Ahora bien, pensar no es exclusivamente producción de conceptos, tarea de la filosofía: como ejercitación de la memoria por el reconocimiento que es, nadie tiene la supremacía, ni la ciencia, ni la filosofía, ni el arte. La opinión de Deleuze-Guattari al respecto, es pertinente: “[e]l pensamiento es pensar a través de conceptos, de funciones, o de sensaciones, sin que ninguna de estas formas de pensar sea mejor que la otra, o más plena, o en síntesis, sea 'el pensar'” (198). Estos autores, desde una perspectiva antihermenéutica, más bien desde la de un “materialismo vitalista” — en expresión de Charles Altieri- (259), admirablemente coincide cuando explican, por ejemplo, cómo son preservados los "bloques de sensaciones":

La sensación compuesta, hecha de percepciones y afectos, desterritorializa el sistema de opinión que acarrea juntamente las percepciones dominantes y los afectos, el medio natural, histórico y social. Al mismo tiempo, esa sensación resulta reterritorializada en el plano de la composición, porque aquí es donde edifica sus aposentos, aquí aparece en el entramado o ensamble de las secciones que circundan a sus componentes: paisajes que han devenido percepciones puras y caracteres que devienen afectos puros. Al mismo tiempo el plano de la composición involucra a la sensación en una desterritorialización más alta haciéndola pasar a través de una suerte de desencaje, que la descubre y fuerza hacia una infinitud cósmica. Como en Pessoa, una sensación no ocupa un lugar en el plano sin extenderlo, dilatándolo así sobre la tierra entera y liberando todas las sensaciones que contiene: abriendo o partiendo, nivelando infinito. Tal vez la peculiaridad del arte consiste en pasar a través de lo finito para redescubrir, restaurar lo infinito. (DeleuzeGuattari 197, énfasis mío)

Una cercanía que propongo al siguiente aforismo de Maurice Blanchot: “Sólo un yo finito (un sí mismo poseedor de finitud en su destino único) va forzosamente a reconocer en la otredad su infinitud responsable" (64). Porque me parece que este aforismo reúne a los filósofos considerados, en torno a una común preocupación por la otredad, que es una apertura infinita, y semilla para el diálogo. Y, simultáneamente, deja sin resolución la pregunta por la poesía; en palabras de Blanchot, en el mismo lugar: "[l]a filosofía, que todo lo cuestiona, tropieza con la poesía que es la cuestión que se le escapa”. ${ }^{8}$

Ensayemos decir lo mismo para poner de relieve una "precisión diferente", en palabras que ya he citado de Alberto Girri, esto es, decir como Julio Cortázar en su Vuelta al día en ochenta mundos, de un modo análogo aunque menos solidario:

8 "La philosophie qui met tout en question, achoppe à la poésie qui est la question qui lui échappe" (150, n17). 
La presencia del monstruo [amable] es otra cosa, algo que se impone como en diagonal o desde el reverso de lo que va sucediendo ese día y los siguientes, y él [López, el protagonista] tiene que admitirlo aunque nadie lo haya visto nunca porque precisamente ese monstruo es un monstruo en cuanto no es, en cuanto está ahí como una nada viva, una especie de vacío que abarca y posee y escuchá lo que me pasó anoche, López, resulta que mi señora. (43)

El poema, como se sabe, menos que de alusiones se conforma de elusiones: "eludere 'escapar jugando'”, recuerda el diccionario etimológico de Joan Corominas (226). Y, por ejemplo, el texto de Cortázar se orienta justamente al revés siendo más alusivo, de “alludere ... 'bromear o juguetear con alguien”" (46). También interesante en este fragmento de Cortázar es esa actividad de la nada, que nos remite al horror barroco al vacío. El poema, en cambio, señala esa "nada viva”, esto es, puede que devenga barroco o neobarroco, pero su máxima violencia radica en señalar la pura nada tal como es. Se trata de la eterna lucha entre el silencio y la palabra.

El poema debe explotar “la ambigüedad a expensas de la convención” (Obra poética I 262). De este modo, cuando las palabras pasan a ser únicamente las más corrientes ya no puede haber una lengua exclusiva autorreferida como poética, ni el poema puede decirse diferente a una dicción común, la pura nada existe entonces donde no hay palabras (ni intersticios), como es obvio. Por ello se da la redundancia en Girri, con esa inserción de lo cotidiano que se ha visto, con la insistencia de la repetición, minuciosamente, ahora, como en la última estrofa de "Metabolismo":

Desde entonces no habló más, se presta a sus ojos y oídos como ojos y oídos, en lugar de mecanismos estúpidos y dóciles, y sentado a la puerta de su casa ve y oye pasar, como nunca antes, a sus vecinos, cadáveres de sus vecinos, y disecándolos en la contemplación engorda de dicha. (Obra poética III 145)

Las cosas se muestran así "tales como son". ${ }^{9}$ Para verlas y oírlas hay que dejar de hablar. Y, como debe ser también, su reverso y metalenguaje: “[e]l poema, escritura como voz para dejar de oír lo que se está escribiendo”(Obra poética III 285). El poema se escribe

9 "Señor: Haz que tu hijo sea como el más/incontaminado de todos tus espejos/y muéstrale las cosas así como él quería,/tales como son”; así es como concluye el poema "Espejo en lo alto” de Olga Orozco (énfasis mío, 107), recogido posteriormente en su libro

Con esta boca, en este mundo. Línea que a su vez viene de un fragmento (el XXII, que Girri tradujo), del poema de Wallace Stevens "The Man with the Blue Guitar":

Poetry is the subject of the poem,

From this the poem issues and

To this returns. Between the two,

Between issue and return, there is 
para que sea espejo, revela Girri: nadie va a encontrar otra cosa que no sea a sí mismo, y, en particular, al propio hacedor. Así Girri, en El motivo es el poema: "Poemas cuyos rasgos destacables derivan de, aproximadamente: 'Yo soy esto. Acéptenme. No arrastro ni preocupaciones ni arrepentimientos. No persigo lo Indubitable, deseo que quienes me lean no se engañen, intuyan que para mejor revelarse a sí mismos no les soy tan esencial '” (Obra poética III 263). Lo propio de lo humano es el lenguaje:

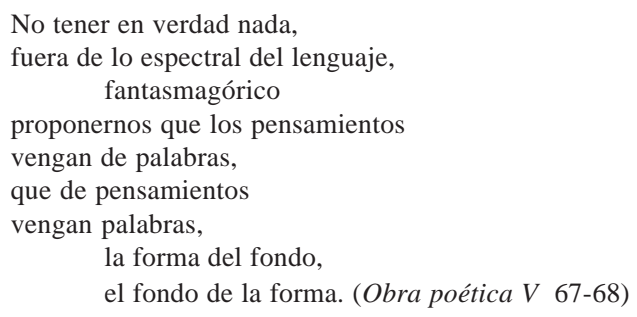

A fuerza de machacar la forma y el fondo con que se trabaja, desaparece lo deslumbrante del poema, lo más exterior e interior poético: modernismo y vanguardia, una y otra cara de la moneda poética recibida por Girri. Quedarse con "la materia a expensas del lenguaje" (Obra poética I 262). Lo que ahora constituye lo maravilloso es empezar con el poema como al despertarse, mirar la hora, el día que hace, cepillarse los dientes. Lo más pegado posible a la vida, pero vigilante de la necesidad del poema que llega a la página. Que a su vez lo aleja de otra de las peores plagas literarias, la confesional. Así, sólo se deja entrar “la imaginería a expensas de tormentos” (Obra poética I 262). Y decir entonces:

Observar por el poema. Ni él ni nosotros conocemos el blanco de la observación. Casi a tientas, aunque nuestro ir a tientas difiere del poema. Pero tal observar, escrutar, es el acercamiento más material de nuestros sentidos. El poema responderá, entonces, a la necesidad de que el lenguaje sea encarnado. Y, al mismo tiempo, nunca reunirá todos los elementos. Algo o mucho quedará afuera; de allí el poema que nace. (Obra poética III 277)

El poema como la precisión seca y ligeramente borrosa del espejo, esa imprecisión que depende de nuestra mirada, sea quizás el máximo símbolo para esta poesía. A fuerza de machacar el lenguaje, hasta los conceptos resultan alcanzados, así se nos dice en “Árbol de estirpe humana":

An absence in reality,

Things as they are. Or so we say.

"La poesía es el asunto del poema; /De allí brota el poema y /Hacia allí retorna. Entre los dos, /Entre nacimiento y vuelta, hay /Una realidad ausente: /Las cosas tales como son. Por así decirlo” (The Palm 143, énfasis mío). 


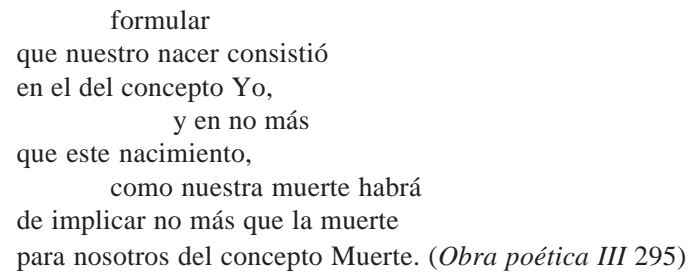

Haroldo de Campos, en el ya citado artículo, hablaba de Lezama Lima y de su “metaforización gongorina de lo cotidiano”, que entonces representaba un escándalo para la novela realista con su insistencia en lo verosímil: "un cocinero, decía, o una dueña de casa, en Lezama, se expresan de la misma manera que un estudiante universitario o un doctor, como si el autor, superpoetizando su prosa, replicase, así, a la introducción de lo conversacional en la poesía moderna” (291, énfasis mío). Ahora bien, ¿cómo se nos ofrece este espejo, este proyecto simbólico, que Girri ha querido elaborar en cada poema? Edgar Morin, en su reciente Amour/ Poésie/ Sagesse, dice en la misma dirección:

Así, en primer lugar hay lo que podríamos llamar el despliegue de la hiperprosa. Despliegue que lo es de un modo de vida amonedado, cronometrado, fragmentado, compartimentado, atomizado, y no sólo de un modo de vida, sino también de un modo de pensar, en donde los expertos especialistas son, tal parece, competentes para todos los problemas. En fin, una invasión de la hiperprosa vinculada al despliegue económicotécnico-burocrático. En estas condiciones, la invasión de la hiperprosa a mi entender ha creado la necesidad de una hiperpoesía. (45, énfasis mío)

Salir de la poesía hacia la vida, como quisieron desde Rimbaud a los surrealistas, y, de manera muy diferente, Alberto Girri. En este sentido, el "realismo" de Girri ha encontrado una hiperpoesía necesaria para responder a la hiperprosa emergente en el mundo moderno. ${ }^{10}$ George Steiner, uno de los ensayistas favoritos de Girri, comentaba que "en la dificultad ontológica, las poéticas de Mallarmé y Heidegger, o de los órficos y los presocráticos, expresan su sentido de la situación falsa del hombre en un entorno de habla erosionada (On Difficulty 44, énfasis mío). Dificultad ontológica que Steiner ha definido de la siguiente manera:

Hay un cuarto orden de dificultad que sucede donde este contrato — entre poeta y lector, entre texto y sentido - se rompe parcial o totalmente. Porque este tipo de dificultad involucra las funciones del lenguaje y las del poema en su actuación comunicativa, y ya que cuestiona los supuestos existenciales que subyacen en el poema como lo conocemos,

10 “Realismo”espiritual, próximo al que define la estadounidense Laura (Riding) Jackson en su introducción a The Poems of Laura Riding: "La poesía podría ser descrita como una institución entregada a la busca de un realismo espiritual, con respecto a la religión como institución consagrada a la busca de un idealismo espiritual” (2, énfasis mío). Próximo nada más, porque esta confianza en un "realismo espiritual” significó para Laura Riding renunciar definitivamente a la poesía. 
propongo llamarla ontológica ... Las dificultades ontológicas nos enfrentan a preguntas vacías acerca de la naturaleza del habla, acerca de la condición de la significación, acerca de la necesidad y el propósito de la construcción que percibimos, grosso modo, con mayor o menor consenso como poema. (On Difficulty 40-41)

Sin embargo, lo particular de este "espejo en lo alto", es que no admite una imagen abyecta. Señalo en este caso, su posible coincidencia con la hermenéutica moderna que es de origen protestante, luterano, esto es, surge al lado de una interpretación individual de los textos sagrados, lo que habría de conducir inexorable, rápida, y simultáneamente, por un lado, a que el principio de autoridad resida en el individuo, y, por el otro, a que esa misma difusión masiva de la Biblia la torne accesible a la estulticia. Joseph Leo Koerner, a quien sigo en este punto, dice refiriéndose al célebre tratado de Erasmo de Rotterdam:

El amor a sí mismo, primer principio de la insensatez, vuelve todo lo que leemos en espejo de nosotros mismos. Así Cristo es el insensato por excelencia, y la salvación depende de nuestra lectura correcta de su testamento.

Un mensaje contradictorio de la autoridad y abyección del sí mismo recorre enteramente la teología de la Reforma. (360)

Imposibilidad de una imagen en este sentido abyecta, porque, como hemos visto, la de Alberto Girri es una escritura que “depende del grado de preparación del lector”, puesto que "no se trata de captar racionalmente el poema, lo que las palabras en lo inmediato dicen, sino de conectarse en lo posible con la intuición original de una experiencia que el hacedor utiliza para componer su texto" (Obra poética VI 186). Hay que acostumbrarse a periodos más o menos prolongados de ascesis poética.

En los ejemplos aquí vistos del poetizar girriano tienden a desaparecer los rasgos subjetivos, hay una disminución del yo que ha sido trabajada con perseverancia de sistema desde sus primeros libros, publicados en la época del auge de una poesía argentina volcada hacia un ensanche de la subjetividad, la de la neorromántica "generación del '40" . ${ }^{11}$ Lo que viene a continuación, es que toda vanidad queda excluida, o, lo que es lo mismo, el primer principio erasmiano del elogio de la estulticia. Vanidad que los románticos -en aquella su "lectura individual”, resurgimiento de la hermenéutica — habrían enfatizado con una cierta pérdida de otredad al favorecer una perspectiva muy subjetiva. T.S. Eliot había dicho que "la emoción del arte es impersonal. Y el poeta no puede alcanzar esta impersonalidad sin someterse plenamente a su trabajo" (59). Actitud que Girri comparte sin el pesimismo reverente de la tradición de Eliot, quien en este punto preciso descuida los trabajos del último Mallarmé. Girri tomará distancias hasta devenir francamente antirromántico, de alguna manera un autor “clásico” de la actualidad por el poderío material y reflexivo de que ha dotado al poema. Una materialidad, subrayo, que, como no puede ser de otro modo después de Mallarmé, señala también los intersticios de la escritura, los blancos de la página, no se desliga de los cuerpos blancos.

\footnotetext{
${ }^{11}$ Para una ampliación de la visión del periodo, véase de César Fernández Moreno La realidad y los papeles. Panorama y muestra de la poesía argentina contemporánea. Madrid: Ediciones de Aguilar, S.A., 1967.
} 
Una zona — la de los blancos— que puede ser ocupada, por ejemplo, desde el punto de vista de una religión monoteísta: “[e]s entre las letras, entre las frases, en el intervalo que las separa donde se obtiene, acurrucada entre los intersticios, una significancia, una claridad que exige ser exhumada, atendida. A esta claridad o significancia Lévinas la denomina pensamiento” (Banon 38). Y para dilatar ese espacio de la letra que incluye lo intersticial Lévinas estaría "más atento entonces a la intertextualidad —el diálogo entre los textos - y a la intersubjetividad — el diálogo entre los maestros_-, que a la etimología, que no sabría, en ningún caso, servir como prueba. Lévinas jamás remite la garantía de un concepto a la filología, y mucho menos a la etimología” (Banon 37, énfasis mío). O, ya desde una perspectiva hermenéutica como la de Charles Taylor, quien de este modo se refiere a los blancos:

A partir de los simbolistas hay una poesía que revela algo por la juxtaposición de las imágenes, o más difícil de explicar aún, por la juxtaposición de las palabras. La epifanía surge entre las palabras o las imágenes, por así decirlo, desde el campo de fuerza que se genera entre ellas, y no desde un referente central que ellas describen mientras se transmutan. (465-66)

Al mismo tiempo, el uso del lenguaje cotidiano en el vocabulario seleccionado por Girri, acerca el artefacto sintáctico al comportamiento de los entes orgánicos, le da posibilidad de reproducirse, abrirse, desterritorializarse (Deleuze-Guattari) en esos otros organismos, los lectores. Enriquece su experiencia vital y literaria, y satisface en la línea conceptual de Gadamer y Ricoeur una “fusión de horizontes” (Horizonverschmelzung) del mundo del lector con el del escritor, una apropiación en este sentido, una racionalidad hermenéutica definida como religación de lo humano. ${ }^{12}$ Tal vez, hasta se permita merodear "una teología creadora de objetos/ que se negarán a ser hostiles a Dios” (Obra poética I 262).

\section{BiBLIOGRAFÍA}

Altieri, Charles. Subjective Agency. A Theory of First-Person Expressivity and its Social Implications. Oxford UK \& Cambridge USA: Blackwell, 1994.

Banon, David. “Lévinas talmudiste”. Emmanuel Lévinas/ Philosophe et Pédagogue. Paris: Éditions du Nadir, 1998. 29-54.

Benjamin, Walter. "The Task of the Translator”. Illuminations. Hannah Arendt, ed. y Harry Zohn, trad. Nueva York: Harcourt Brace Jovanovich, Inc., 1968. 69-82.

Blanchot, Maurice. The Writing of the Disaster. Ann Smock, trad. Lincoln/Londres: Nebraska University Press, 1995.

\footnotetext{
${ }^{12}$ Señalo aquí la relación entre religar y religión, etimológicamente "reunir lo fragmentado", que parece neurálgica en un proyecto tan coherente como es la poesía de Girri. De suma importancia es lo que Eugenio Trías informa al respecto: "En el encuentro del testigo con el texto bíblico — que corresponde a la "tercera edad" originadora de "una genuina ciudad de Dios aquí en la Tierra"en la lectura de éste, se produce el acto propio y específico de la religatio en clave espiritual: el efectivo encuentro y relación entre lo sagrado y el testigo” (434 y 495, énfasis mío).
} 
Campos, Haroldo de. "Superación de los lenguajes exclusivos”. América Latina en su literatura. César Férnandez Moreno, ed. 15a. ed. México, DF: Siglo XXI Editores/ UNESCO, 1996. 279-300.

Corominas, Joan. Breve diccionario etimológico de la lengua castellana. 3a. Ed. Madrid: Editorial Gredos, S.A., 1973.

Cortázar, Julio. La vuelta al día en ochenta mundos. Madrid: Editorial Debate, 1993.

Cueto, Sergio. Seis estudios girrianos. Rosario: Beatriz Viterbo Editora, 1993.

Deleuze, Gilles y Félix Guattari. What is Philosophy? Hugh Tomlinson y Graham Burchell, trads. Nueva York: Columbia University Press, 1994.

Eliot, T. S. "Tradition and the Individual Talent”. The Sacred Wood. Londres: Methuen \& Co. Ltd., 1950. 47-59.

Girri, Alberto. Obra poética I. Buenos Aires: Ediciones Corregidor, 1977. Obra poética II. Buenos Aires: Ediciones Corregidor, 1978. Obra poética III. Buenos Aires: Ediciones Corregidor, 1980. Obra poética IV. Buenos Aires: Ediciones Corregidor, 1984. Obra poética V. Buenos Aires: Ediciones Corregidor, 1988. Obra poética VI. Buenos Aires: Ediciones Corregidor, 1991.

Heidegger, Martin. Poetry, Language, Thought. Albert Hofstadter, trad. Nueva York: Harper \& Row, 1971.

Koerner, Joseph Leo. The Moment of Self-Portraiture in German Renaissance Art. Chicago: Chicago University Press, 1993.

Kristeva, Julia. La révolution du langage poétique. L'avant garde à la fin du XIXe siècle: Lautréamont et Mallarmé. Paris: Éditions du Seuil, 1974.

Lévinas, Emmanuel. "Reality and Its Shadow”. The Levinas Reader. Seán Hand, ed. Oxford \& Cambridge: Blackwell, 1989. 129-43.

Man, Paul de. Blindness and Insight. Essays in the Rethoric of Contemporary Criticism. Minneapolis: Minnesota University Press, 1983. The Resistance to Theory. Minneapolis: Minnesota University Press, 1989.

Morin, Edgar. Amour/ Poésie/ Sagesse. Paris: Éditions du Seuil, 1997.

Orozco, Olga. "Espejo en lo alto”. Alberto Girri. Homenaje. Alina Diaconú, comp. Buenos Aires: Editorial Sudamericana, 1993. 105-07.

Ricoeur, Paul. Interpretation Theory: Discourse and the Surplus of Meaning. Fort Worth, TX: Christian University Press, 1976.

Riding, Laura. The Poems of Laura Riding. Nueva York: Persea Books, Inc., 1980. y Robert Graves. A Survey of Modernist Poetry. Nueva York: Haskell House Publishers Ltd., 1969.

Steiner, George. On Difficulty and Other Essays. Oxford/Nueva York/Toronto/Melbourne: Oxford University Pres, 1980. After Babel. Aspects of Language \& Translation. $3^{\text {rd }}$. Ed. Oxford/Nueva York: Oxford University Press, 1998.

Stevens, Wallace. The Palm at the End of the Mind. Nueva York: Vintage Books, 1990. Collected Poetry \& Prose. Nueva York: The Library of America, 1997.

Taylor, Charles. Sources of the self. The Making of the Modern Identity. Cambridge: Harvard University Press, 1989. 
Trías, Eugenio. La edad del espíritu. Barcelona: Ediciones Destino, 1994. 